Part of Journal of Research of the National Bureau of Standards, Volume 16, May 1936

\title{
MECHANISM OF THE SULFUR LABILITY IN THE ALKALI DEGRADATION OF WOOL PROTEIN
}

\author{
By J. A. Crowder and Milton Harris ${ }^{1}$
}

\section{ABSTRACT}

It is the purpose of this paper to describe the behavior of sulfur in wool under conditions which are very different from those ordinarily used in studies on sulfur lability and to point out a probable mechanism by which sulfur is split from wool during alkali treatment. The data indicate that the primary process in the alkali cleavage of the disulfide linkage consists in a hydrolytic rupture of the disulfide group with the formation of a sulfhydryl compound and a sulfenic acid. The sulfenic acid is extremely reactive and unstable in alkaline solution and immediately loses hydrogen sulfide and forms an aldehyde. The results of the investigation indicate that the existence of labile sulfur in proteins is not an indication that the bulk of the sulfur is present in more than one form.

CONTENTS

II. Experimental procedure $-\ldots$

III. Results and discussion

IV. References $\ldots \ldots$

\section{INTRODUCTION}

The lability of sulfur in cystine and cysteine and their derivatives, and in various disulfides, mercaptans, and proteins has recently received much attention. Excellent reviews and bibliographies on the voluminous literature on this subject are recorded in the papers of Gortner [1] ${ }^{2}$ and Clarke [2] and their collaborators and for that reason need not be discussed here.

Labile sulfur is an arbitrary name given to that portion of the sulfur which splits off from sulfur-containing substances on treatment with various alkalies or with alkaline solutions of various reagents such as lead acetate, lead nitrate, etc. It is obvious that the value obtained for the amount of labile sulfur will depend on the method used and the specific conditions of treatment. There have been postulated several mechanisms, which will be discussed later, for the splitting of sulfur from cysteine, cystine, and other mercaptans and disulfides. In the case of proteins, however, results which have appeared to be anomalous have led a number of in-

\footnotetext{
1 Research Associates at the National Bureau of Standards, representing the American Association of Textile Chemists and Colorists.

${ }_{2}$ The numbers in brackets here and throughout the text refer to the references at the end of this paper.
} 
vestigators [3] to assume the existence of a number of sulfur combinations in proteins.

The results of the present investigation make it unnecessary to assume that the existence of labile sulfur in proteins is an indication that the bulk of the sulfur is present in more than one form. It is the purpose of this paper to describe the behavior of sulfur in wool under conditions which are very different from those ordinarily used in studies on sulfur lability, and to point out a probable mechanism by which sulfur is split from wool during alkali treatment.

\section{EXPERIMENTAL PROCEDURE}

Purified wool yarn, the preparation and properties of which have been described elsewhere [4], was used in this work. The alkali treatments were performed in a 2-liter filtering flask, fitted with a dropping funnel for passing liquid into the flask and having the sideneck connected to a suction pump for removal of the liquid. The flask was immersed in a water bath at $65^{\circ} \mathrm{C}$. During the treatments, every precaution was taken to keep oxygen out of the reaction mixture. A 6-g sample of wool was placed in the suction flask and the air exhausted and replaced with nitrogen. $600 \mathrm{ml}$ of a $0.05 \mathrm{~N}$ solution of sodium hydroxide, previously boiled to remove dissolved air, was then added. The flask was shaken frequently. At the end of each treatment, the supernatant liquor was drawn off and the wool washed by running freshly distilled water through the flask until the washings were no longer alkaline to phenolphthalein. The water remaining in the flask was drawn off and the wool was partially dried under reduced pressure at $65^{\circ} \mathrm{C}$ for two hours. The wool was then rapidly transferred to a vacuum desiccator, where it was dried to constant weight over calcium chloride. After drying, all samples were stored in an atmosphere of nitrogen.

\section{RESULTS AND DISCUSSION}

Samples of purified wool were treated as previously described for varying periods of time. The loss in weight of the wool and the sulfur and cystine content of the alkali-treated wool are given in

$\mathrm{T}_{\mathrm{ABLE}}$ 1.-Effect on wool of the continued action of $0.05 \mathrm{~N}$ solution of sodium hydroxide at $65^{\circ} \mathrm{C}$

\begin{tabular}{|c|c|c|c|}
\hline & \multirow[b]{2}{*}{$\begin{array}{l}\text { Loss in } \\
\text { weight }\end{array}$} & \multicolumn{2}{|c|}{ Alkali-treated wool } \\
\hline Time of treatment & & $\begin{array}{l}\text { Sulfur } \\
\text { content }\end{array}$ & $\begin{array}{l}\text { Cystine con- } \\
\text { tent, by Sul- } \\
\text { livan method }\end{array}$ \\
\hline $\begin{array}{l}\text { Minutes: } \\
\quad 0 \\
150 \\
45\end{array}$ & $\begin{array}{l}\text { Percent } \\
0 \\
2.27 \\
3.52 \\
4.67\end{array}$ & $\begin{array}{r}\text { Percent } \\
3.72 \\
2.91 \\
2.56 \\
2.35\end{array}$ & $\begin{array}{r}\text { Percent } \\
13.40 \\
6.91 \\
4.85 \\
5.13\end{array}$ \\
\hline $\begin{array}{l}\text { Hours: } \\
\quad 2 . \\
\quad 4 \\
\quad 86 \mathrm{a}\end{array}$ & $\begin{array}{r}6.4 \\
9.38 \\
15.21 \\
61.50\end{array}$ & $\begin{array}{l}2.24 \\
2.13 \\
2.03 \\
2.28\end{array}$ & $\begin{array}{l}\text { 4. } 41 \\
\text { 3. } 70 \\
\text { 2. } 64 \\
2.65\end{array}$ \\
\hline
\end{tabular}

a The samples became gelatinous and part of the residual wool was lost during washing. The accuracy of these values are questionable. 
table 1. The results ${ }^{3}$ are in good agreement with those obtained previously [4] although no precautions were taken to exclude oxygen in the earlier experiments.

The data indicate a rapid splitting off of a portion of the sulfur during the early stages of the treatment. After about four hours the sulfur content approaches a constant value, which is not significantly changed on further treatment.

The conditions under which these experiments were carried out, namely, the temperature and concentration of the alkaline solutions and the duration of treatment, are very mild compared with those generally used in determining the labile sulfur in cystine, cysteine, or their derivatives. The extreme ease with which approximately onehalf of the sulfur is removed from wool under such comparatively mild conditions suggests that the first step in the alkali degradation of wool is a splitting of the disulfide linkage into one labile and one comparatively stable sulfur group.

Two mechanisms for the sulfur lability in cysteine and its derivatives and in disulfides have been recently advanced by Nicolet [5] and by Schöberl and Wierner [6]. The former suggests that the removal of sulfur from cysteine by alkalies takes place as a 1,4elimination of hydrogen sulfide from an intermediate enolized form according to the following equations:

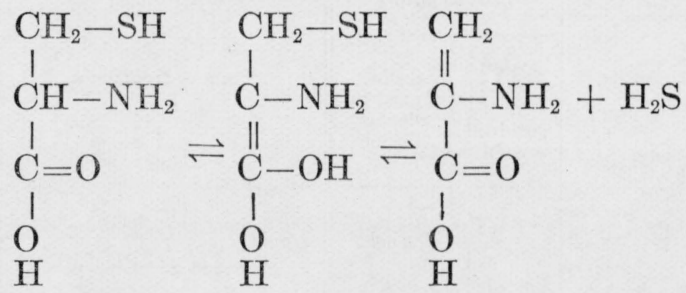

He also suggests that from cystine, RSSH or eventually $\mathrm{H}_{2} \mathrm{~S}_{2}$, would split out.

Schöberl and Wierner studied the alkaline cleavage of disulfides and found evidence that the primary process in the cleavage of aliphatic disulfides of a definite type consisted in a hydrolytic rupture of the disulfide linkage with the formation of a sulfydryl compound and a sulfenic acid according to the following scheme:

$$
\mathrm{R}-\mathrm{CH}_{2}-\mathrm{S}-\mathrm{S}-\mathrm{CH}_{2} \mathrm{R} \longrightarrow \mathrm{RCH}_{2} \mathrm{SH}+\mathrm{HOSCH}_{2} \mathrm{R}
$$

The sulfenic acid, being extremely reactive and unstable in alkaline solution, immediately loses $\mathrm{H}_{2} \mathrm{~S}$ and forms an aldehyde according to equation 3.

$$
\mathrm{RCH}_{2}-\mathrm{SOH} \longrightarrow \mathrm{RCHO}+\mathrm{H}_{2} \mathrm{~S}
$$

They also postulate that in the presence of air, the sulfhydryl groups will be reoxidized to disulfide groups, after which the reaction in equation 2 would again take place. Even though air were not excluded during the alkali treatment of wool, it would be very doubtful whether such a reaction might take place, since the sulfhydryl groups are held in fixed positions in the wool molecule and would thus be kept from recombining.

\footnotetext{
${ }^{3}$ In comparing the values obtained in the present work with those in the earlier experiments, it should be noted that the data in this paper are calculated on a dry-wool basis, while those in the previous experiments were based on the weight of the conditioned wool.
} 
The experimental evidence in the present investigation indicates that the alkali degradation of wool proceeds according to equations 2 and 3 . When the alkali-treated samples were tested for aldehydic properties with Schiff's reagent, it was found that an intense violet-red color was formed on the wool in a few seconds, while the untreated wool was colored only a faint pink by the same treatment. Similarly the alkali-treated samples gave positive sulfhydryl reactions with ammoniacal sodium nitroprusside solutions, while tests on the untreated wool were negative. It can also be easily demonstrated that the sulfur which is split off from the wool is in the form of inorganic sulfides. If an aliquot of the mother liquor from the alkali treatment is saturated with bromine and heated on a steam bath for one-half hour, the sulfur is oxidized to sulfate and can be determined as barium sulfate. It has been shown that the sulfur in wool or in cystine is not oxidized to sulfate under these conditions. The losses in sulfur of the wool, calculated from the sulfur contents of the alkali-treated samples and also from the sulfur found in the mother liquor are given in table 2.

TABLE 2.-Loss of sulfur from wool resulting from the continued action of $0.065 \mathrm{~N}$ solutions of sodium hydroxide at $65^{\circ} \mathrm{C}$

\begin{tabular}{|c|c|c|c|c|c|}
\hline \multirow[b]{2}{*}{ Time of treatment } & \multicolumn{2}{|c|}{ Loss in sulfur } & \multirow[b]{2}{*}{ Time of treatment } & \multicolumn{2}{|c|}{ Loss in sulfur } \\
\hline & $\begin{array}{l}\text { Calcu- } \\
\text { lated } \\
\text { from } \\
\text { residual } \\
\text { wool }\end{array}$ & $\begin{array}{l}\text { Sulfur } \\
\text { found in } \\
\text { mother } \\
\text { liquor }\end{array}$ & & $\begin{array}{l}\text { Calcu- } \\
\text { lated } \\
\text { from } \\
\text { residual } \\
\text { wool }\end{array}$ & $\begin{array}{l}\text { Sulfur } \\
\text { found in } \\
\text { mother } \\
\text { liquor }\end{array}$ \\
\hline $\begin{array}{l}\text { Minutes: } \\
10 \\
20 \\
30 \\
40 \\
50\end{array}$ & $\begin{array}{r}\mathrm{mg} / \mathrm{g} \text { of } \\
\text { wool } \\
4.4 \\
8.8 \\
10.1 \\
10.4 \\
10.9\end{array}$ & $\begin{array}{r}\mathrm{mg} / \mathrm{g} \text { of } \\
\text { wool } \\
4.0 \\
7.4 \\
9.7 \\
9.8 \\
10.2\end{array}$ & $\begin{array}{l}\text { Hours: } \\
\quad 1 \\
2 \\
3 \\
4 \\
5\end{array}$ & $\begin{array}{r}\mathrm{mg} / \mathrm{g} \text { of } \\
\text { wool } \\
11.6 \\
12.8 \\
14.0 \\
14.5 \\
14.9\end{array}$ & $\begin{array}{r}\mathrm{mg} / \mathrm{g} \text { of } \\
\text { wool } \\
11.3 \\
12.1 \\
13.6 \\
14.0 \\
14.8\end{array}$ \\
\hline
\end{tabular}

It has been previously mentioned that under the conditions of these experiments, cysteine and its derivatives would be comparatively stable. That the sulfur in the cysteine in wool (obtained by reducing wool in alkaline solution) is stable under these conditions is readily shown by treating wool with $0.05 \mathrm{~N}$ solution of sodium hydroxide containing 1 percent of sodium sulfide. After 2 hours' treatment the wool loses about 5 percent of its sulfur, whereas in the same treatment with no sodium sulfide present wool loses about 40 percent of its sulfur.

It is apparent that since the wool is not in solution, not all of the disulfide groups will react with alkali simultaneously. It is probable, therefore, that sodium sulfide, which is immediately formed by the action of the sodium hydroxide on some of the disulfide groups, will tend to reduce unreacted disulfide groups to sulfhydryl groups and make them more stable towards the alkali. On the basis of this, it follows that if the sodium sulfide is removed from contact with wool as rapidly as possible, the sulfur content of the residual wool should be lower than that of wool which is allowed to remain in contact with the sodium sulfide. In order to test this 5- and 12-g samples of 
wool were placed in $400-\mathrm{ml}$ flasks and a $0.05 \mathrm{~N}$ solution of sodium hydroxide at $65^{\circ} \mathrm{C}$ was allowed to flow continuously into the flasks so that the wool was in practically constant contact with fresh alkali. After 4 hours' treatment, the samples were washed and dried as previously described and analyzed for loss in weight and sulfur and cystine contents. The results are recorded in table 3 and are compared with results obtained on a regular 4-hour sample (table 1). The data constitute further evidence that the labile sulfur comes from the formation of a sulfur compound other than cysteine and that cysteine is relatively stable under the conditions of these experiments. It is also of interest to note that in treatment (4), table 3, the 50 percent splitting off of sulfur that would be expected under ideal conditions is closely approached.

TABLE 3.-Comparison of the effect on wool of standing and flowing baths of $0.05 \mathrm{~N}$ solutions of sodium hydroxide at $65^{\circ} \mathrm{C}$

[Time of treatment 4 hours]

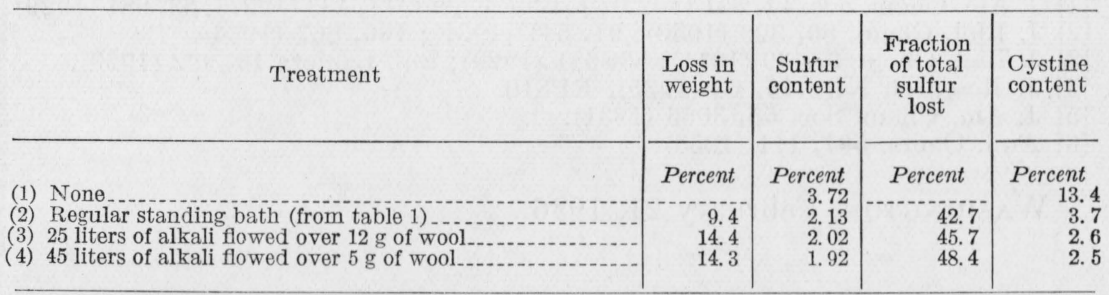

While qualitative evidence is readily obtained which indicates the presence of sulfhydryl and aldehydic groups in the alkali-treated wool, tests for the presence of those groups in the hydrochloric acid hydrolysate obtained in the analysis for cystine were definitely negative. However, when the reactivity of the aldehydic and sulfhydryl groups formed in the hydrolysate is considered, it is not surprising that negative tests were obtained. Under the conditions of the hydrolysis, namely, $6 \mathrm{~N}$ hydrochloric acid at $120^{\circ} \mathrm{C}$ for 9 hours, it is very probable that recombination between the aldehydic and sulfhydryl groups may take place. A suggested mechanism for such a reaction would be the formation of a thioacetal. To test for the formation of stable thiocompounds, hydrolysis was carried out in $18 N$ sulfuric acid. Acid of this strength is known to cleave thio-compounds which are stable to more dilute acids. The results in table 4 show that the values obtained by use of $18 N$ sulfuric acid are definitely higher than the values obtained with $6 N$ acid. The somewhat higher values for cystine obtained by the Folin-Marenzi method are in accord with results obtained by other investigators and may be attributed to lack of specificity of the Folin-Marenzi reagent. It may be concluded, however, that a more stable thio-compound is formed in the dilute acid hydrolysate. ${ }^{4}$ There is also a possibility that some of the sulfhydryl formed in the wool during the alkaline treat-
mentimay react to form a stable thio-compound even before hydrolysis. Further investigations are now in progress. 
TABLE 4.-Cystine analysis of alkali-treated wool using $6 N$ and $18 N$ sulfuric acid for the hydrolysis

\begin{tabular}{|c|c|c|c|c|c|c|c|}
\hline \multirow{2}{*}{$\begin{array}{l}\text { Time of } \\
\text { treatment }\end{array}$} & \multirow{2}{*}{$\begin{array}{l}\text { Sulfur } \\
\text { content }\end{array}$} & \multicolumn{2}{|c|}{$\begin{array}{l}\text { Cystine content, Sullivan } \\
\text { method }\end{array}$} & \multirow{2}{*}{$\begin{array}{c}\text { Increase } \\
\text { in } \\
\text { cystine } \\
\text { content }\end{array}$} & \multicolumn{2}{|c|}{$\begin{array}{l}\text { Cystine content, Folin- } \\
\text { Marenzi method }\end{array}$} & \multirow{2}{*}{$\begin{array}{l}\text { Increase in } \\
\text { cystine } \\
\text { content }\end{array}$} \\
\hline & & $6 \mathrm{~N} \mathrm{H}_{2} \mathrm{SO}_{4}$ & $18 \mathrm{NH}_{2} \mathrm{SO}_{4}$ & & $6 \mathrm{~N} \mathrm{H}_{2} \mathrm{SO}_{4}$ & $18 \mathrm{~N} \mathrm{H}_{2} \mathrm{SO}_{4}$ & \\
\hline $\begin{array}{c}\text { Hours } \\
0 \\
4 \mathrm{a}^{2}\end{array}$ & $\begin{array}{r}\text { Percent } \\
3.72 \\
2.02 \\
2.03\end{array}$ & $\begin{array}{r}\text { Percent } \\
13.3 \\
2.2 \\
2.6\end{array}$ & \begin{tabular}{r|} 
Percent \\
13.0 \\
3.1 \\
3.5
\end{tabular} & $\begin{array}{r}\text { Percent } \\
-2 \\
+41 \\
+35\end{array}$ & $\begin{array}{r}\text { Percent } \\
13.2 \\
3.6 \\
2.9\end{array}$ & \begin{tabular}{r|} 
Percent \\
13.0 \\
4.6 \\
3.6
\end{tabular} & $\begin{array}{r}\text { Perceni } \\
-2 \\
+28 \\
+24\end{array}$ \\
\hline
\end{tabular}

a Sample 3 (table 3), which was treated with flowing alkali solution.

The work was made possible, in part, by a grant from The Chemical Foundation, and we wish to express our appreciation for the aid.

\section{REFERENCES}

[1] J. Am. Chem. Soc. 44, 341 (1922); J. Biol. Chem. 92, 433 (1927); 83, 681 (1929).

[2] J. Biol. Chem. 89, 399 (1930); 94, 541 (1931); 106, 667 (1934).

[3] J. Biol. Chem. 9, 439 (1911); 83, 681 (1929); Bol. Laniera 43, 992 (1929).

[4] J. Research NBS 15, 63 (1935), RP810.

[5] J. Am. Chem. Soc. 55, 3066 (1931).

[6] Ann. Chem. 50\%, 111 (1933).

Washington, February 21, 1936. 